\title{
Ticks collected from reptile species on Small Nemrut Mountain (Tatvan/Bitlis/Turkey)
}

\author{
ALI BILGIN YILMAZ, ÖZLEM ORUNÇ KILINÇ*, ÖZDEMIR ADIZEL, \\ EMRE BULUM**, NAZMI YÜKSEK ${ }^{* * *}$
}

\author{
Van Health High School, University of Van Yuzuncu Yil, 65080, Van, Turkey \\ *Özalp Vocational High School, University of Van Yuzuncu Yil, 65800, Van, Turkey \\ **Faculty of Science, Department of Biology, University of Van Yuzuncu Yil, 65080, Van, Turkey \\ ${ }^{* * *}$ Faculty of Veterinary Science. Department of Internal Diseases, University of Van Yuzuncu Yil, 65080, Van, Turkey
}

Yılmaz A. B., Orunç Kılınç Ö., Adızel Ö., Bulum E., Yüksek N. Ticks collected from reptile species on Small Nemrut Mountain (Tatvan/Bitlis/Turkey)

\section{Summary}

This study aims to identify the ticks living on reptiles of Small Nemrut Mountain as ectoparasites. Field work was carried out between May and November 2016. The mountain which attracts a lot of visitors is an extinct volcano. There are settlements close to the mountain. Furthermore, the area is the upland for the local fauna. 12 reptile species live on the mountain. In the scans on reptiles living in the area, the Hyalomma aegyptium type tick is identified on Testudo graeca (Common Tortoise) and Darevskia valentini (Valentin's Lizard) species. The infestation rate was found to be $66.66 \%$ on tortoises and $28.57 \%$ on lizards. In the resources, it was reported that Borellia turcica, Theileria spp, Borellia burgdorferi, Anaplasma phagocytophilum, which are microorganisms with high pathogenicity in humans and animals, are isolated from $H$. aegyptium collected from tortoises. In addition, it was reported in various studies that Hyalomma aegyptium is a reservoir host for Hemoliva mauritanica which is a blood parasite that has been identified to intensively cause diseases in tortoises.

Keywords: Small Nemrut Mountain, Nemrut Crater, Hyalomma aegyptium, Testudo graeca, Darevskia valentini

Ticks are a group of ectoparasites which have a broad distribution on earth. Ticks mostly suck blood from warm blooded animals such as birds and mammals. In addition, they may feed on cold blooded animals such as amphibians and reptiles. Ticks are to a large extent a potential vector of human and animal pathogens. These parasites may cause serious problems by distributing pathogens among animal owners and animals $(2,24)$. Among Hyalomma type ticks, Hyalomma aegyptium is known as the tortoise tick due to its specificity to tortoises on which mature forms of ticks live $(15,27,29)$. This specificity is sometimes so high that it has caused that the presence of $H$. aegyptium is considered as an indirect indicator of the presence of Testudo graeca $(28,30)$. Although larvae and nymphs of $H$. aegyptium tend to attach onto $T$. graeca, on a lower rate they may attach to and suck blood from lizards, birds, small mammals and humans $(1,21,31)$. It was reported in recent studies that $H$. aegyptium is present in various habitats, such as forests, woodlands, steps and deserts in the Palearctic Region, Middle East, Northern Africa, Balkans and Central Asia (14).
One hundred eighty four amphibian and reptile species live on Continental Europe (13). This number is around 163 in Turkey $(5,26)$. According to recent studies, there are 6 amphibian species and 31 reptile species within the borders of Bitlis Province (23). Three amphibian species and 12 reptile species were identified around the Small Nemrut Mountain in Bitlis (9).

Testudo graeca is a tortoise species living in the Northern Africa (Morocco, Algeria, Tunis, Libya), Middle East (Lebanon, Syria, Iraq, Jordan), Europe (Romania, Bulgaria, Greece, Turkey, Spain) and Asia (Azerbaijan, Armenia, Turkmenistan, Georgia, Iran, Afghanistan) $(6,8,10)$. In Turkey, this tortoise species was identified in Eskişehir, Ankara, İstanbul, İzmir, İznik, Sapanca, Bornova, Menderes Valley, Bilecik, Bursa, Yenişehir, Akşehir, Afyonkarahisar, Sandikl1, Adana, Antalya, Gaziantep, Mardin, Mersin, İskenderun, Van and Hakkâri $(7,20)$. Darevskia valentine species is spread throughout the Middle East, as well as in Central Anatolia, Black Sea and Eastern Anatolia Regions in Turkey $(5,26)$. This study was 
conducted to identify the tick species on reptile species living on the Small Nemrut Mountain as ectoparasites.

The purpose of this study is to determine the species of ticks obtained from reptiles in the identified area and to set a light to the effects of these ticks on humans and livestock.

\section{Material and methods}

Collecting samples and study field. Located in the Eastern Anatolia Region of Turkey and on the west shore of Lake Van, the Small Nemrut Mountain is a dormant active volcano on $38^{\circ} \mathrm{C} 37^{\prime} 10^{\prime \prime}$ North Latitude and $42^{\circ} \mathrm{C} 14^{\prime} 28^{\prime \prime}$ East Longitude, which was formed following volcanic eruptions. The coldest month is January and mean temperature is $-5.9^{\circ} \mathrm{C}$ and the hottest month is July and mean temperature is $18.5^{\circ} \mathrm{C}(19)$. The material of the study carried out on and around Small Nemrut Mountain between May and November 2016 consists of ticks living on the reptiles living within the study field. The reptiles caught were examined for ticks. 11 snakes of various species, 48 tortoises and 21 Valentin's Lizards were examined for tick infestation. The ticks duly collected from infested animals using forceps were put in numbered bottles containing 70\% Ethyl alcohol and brought to the laboratory. Priority was attached to cleaning unwanted materials such as skin, dust and sand collected with ticks during collection. Ticks were identified with a stereomicroscope (Nikon SMZ 1270i) using related literatures $(3,16)$.

\section{Results and discussion}

No tick was identified on the 11 snakes which were examined for ticks. It was determined that 32 out of 48 tortoises and 6 out of 21 lizards examined were infested with ticks. 100 ticks were collected from 32 infested tortoises and 9 ticks were collected from 6 infested lizards. It was determined that 41 were male and 59 were female out of the 100 ticks collected from tortoises, and 4 were male and 5 were female out of the 9 ticks collected from lizards. 109 ticks collected were all identified as $H$. aegyptium. It was visible that ticks were attached to the fore and hind legs on the tortoises and lizards. The infestation rate was found as

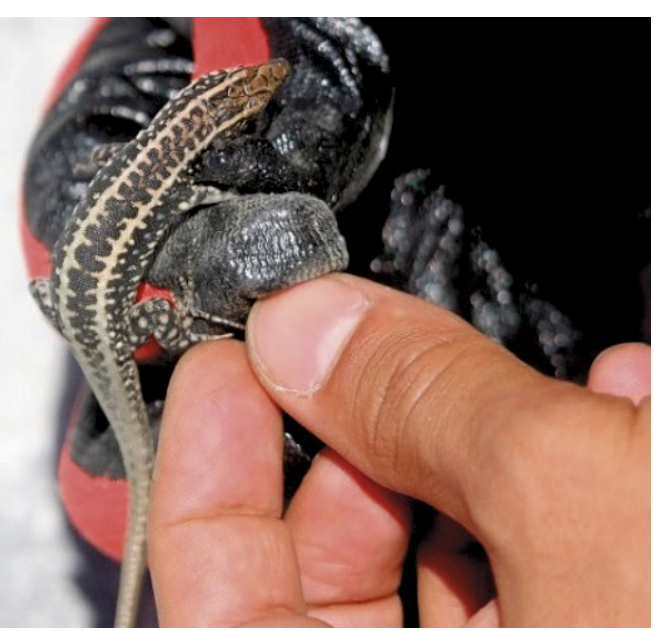

Fig. 3. Lizard examined for ticks

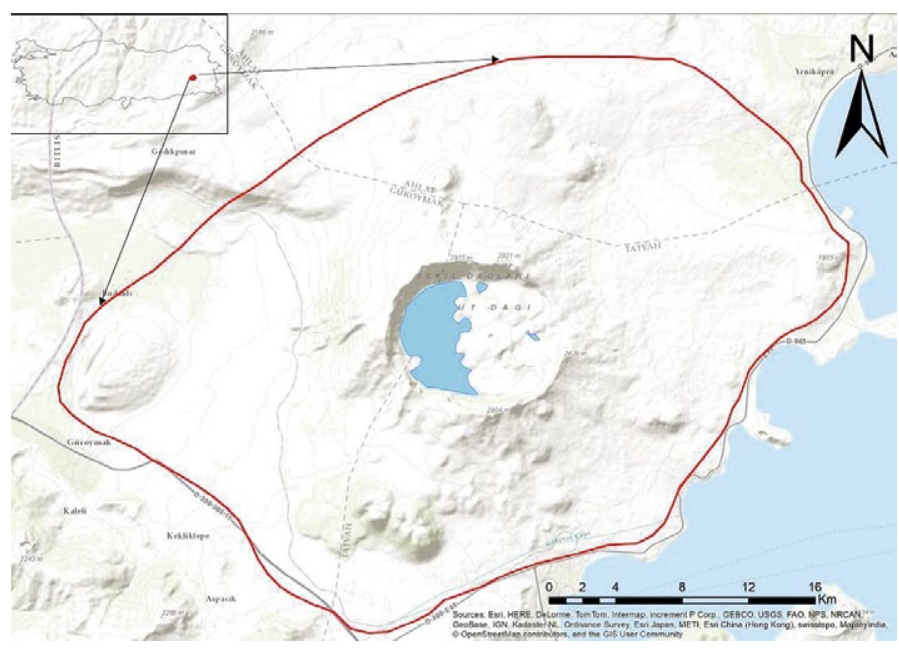

Fig. 1. Map of study field

$66.66 \%$ in tortoises and $28.57 \%$ in lizards. The total number of ticks per tortoises was found as 2.08 , and the total number of ticks per lizards was found as 1.5. The identified ticks were photographed.

Ticks are one of the most important ectoparasites of humans and animals especially in tropical and subtropical regions $(17,18)$. Out of 899 tick species in the world, approximately $10 \%$ play a role in carrying over 200 zoonotic agents such as bacteria, virus, rickettsia

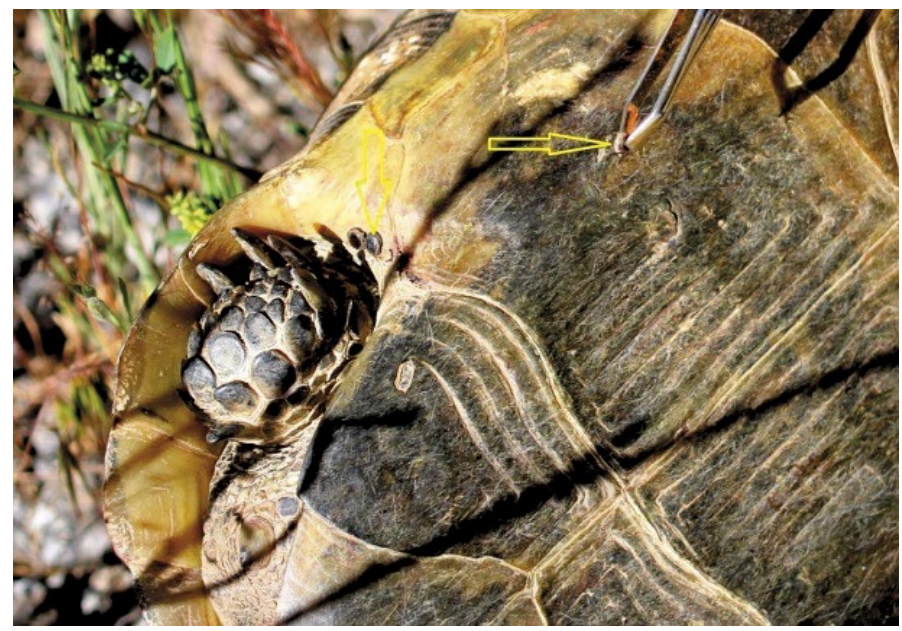

Fig. 2. Collecting ticks from tortoise

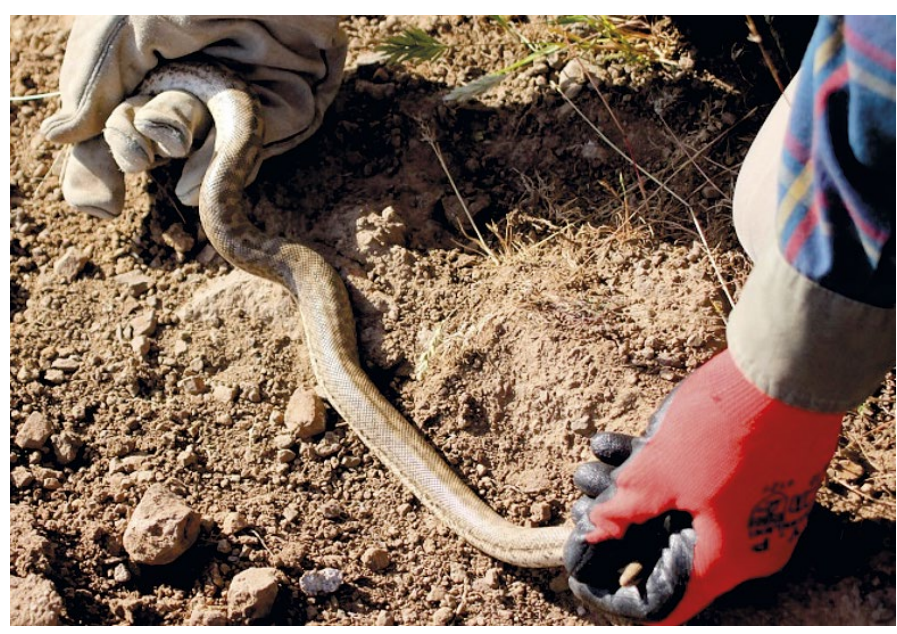

Fig. 4. Snake examined for ticks 
and protozoa $(12,22)$. Numerous studies have been conducted in the world to identify the ectoparasites in tortoises and lizards. In a study carried out in Iran, 129 lizards of 3 species and 25 tortoises (T. graeca) were examined. It was reported that lizards (Trachylepis vit-

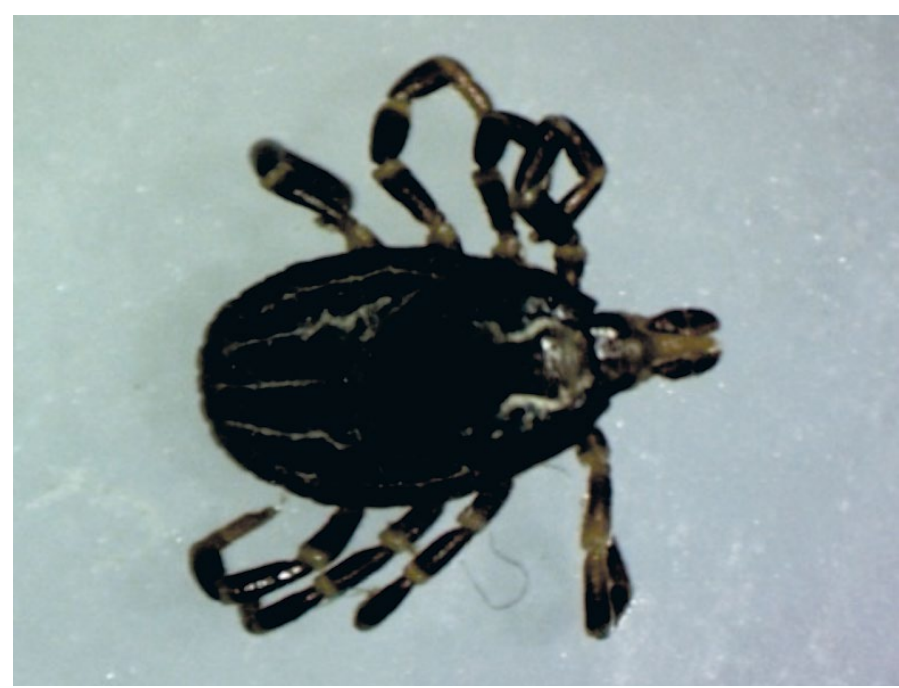

Fig. 5. Hyalomma aegyptium (female)

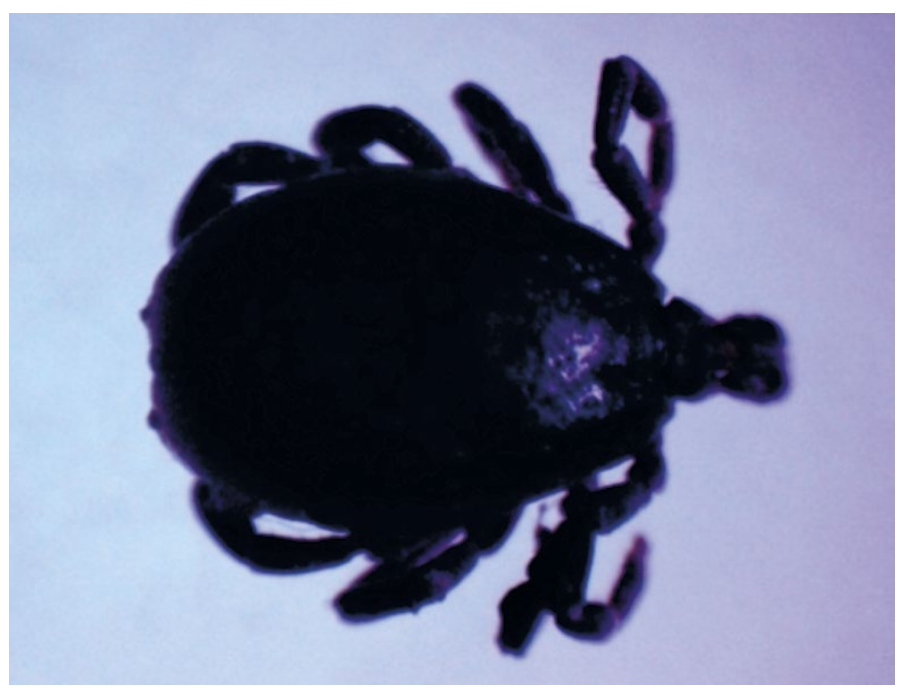

Fig. 6. Hyalomma aegyptium (male)

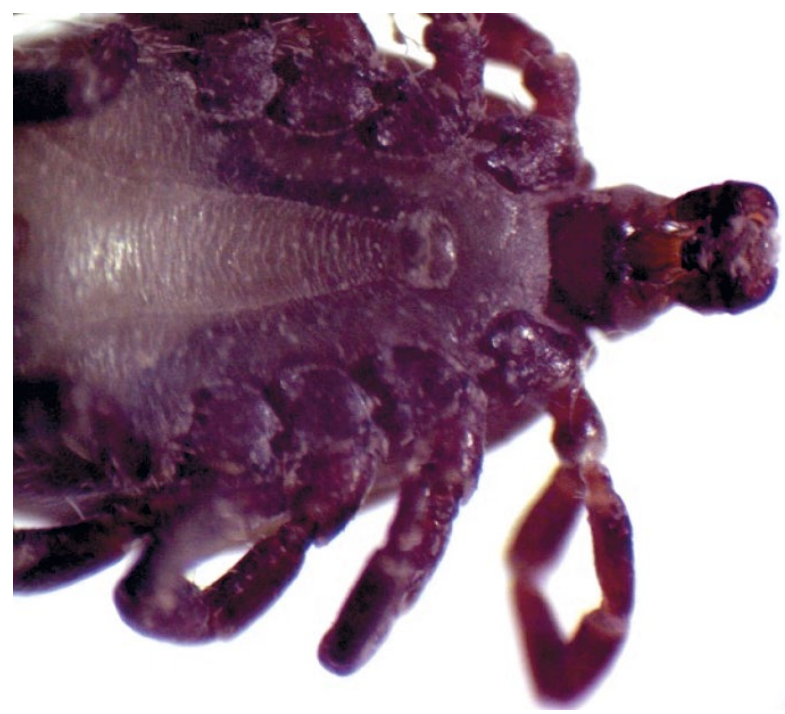

Fig. 7. Male tick coxa 1 external spur tata, Trachylepis aurata, Trapelus lessonae, Laudakia nupta) were infested at the rate of $60.46 \%$ and tortoises were infested at the rate of $100 \%$ with ticks. It was reported that $39.53 \%$ of the ticks identified on lizards were H. aegyptium, $13.95 \%$ were Rhipicephalus sanguineus and $17.05 \%$ were Haemaphysalis spp. and $100 \%$ of the ticks identified on tortoises were H. aegyptium (25). In a study carried out in Balkan countries, 1327 ticks were collected from 211 tortoises of three species (Testudo marginata, Testudo graeca, Testudo hermanni), and it was reported that the identified tick species were $H$. aegyptium, Haemaphysalis sulcata, Haemaphysalis inermis, Rhipicephalus sanguineus (29). Dudek et al. examined 500 lizards (Lacerta agilis) for ticks in Poland and reported that they identified 839 ticks of Ixodes ricinus species (11). In Turkey, Aydin et al. identified that $40.6 \%$ of the tortoises were infested with $H$. aegyptium in their study on 32 tortoises in Marmara Region (23). In Aysul et al.'s study on 52 tortoises in the Thrace Region, it was determined that $98.2 \%$ of the tortoises were infested with ticks, and that $22.22 \%$ of the ticks were female and $77.78 \%$ were male (4). In the study of Yilmaz et al. carried out in Van on 38 tortoises, it was reported that all of the tortoises were infested with $H$. aegyptium (32). With this study, 1 tick species of 1 genealogy was identified on tortoises (T. graeca) and lizards (D. valentine), and it was found that $66.66 \%$ of the tortoises and $28.57 \%$ of the lizards were infested with $H$. aegyptium. It was identified that these rates are parallel with the studies conducted. It was thought that the reason of high rates of ticks on tortoises and lizards is because the number of female ticks are higher than the male ticks in the tick population. In the study, all of the ticks collected from tortoises and lizards in and around Nemrut Mountain were identified as $H$. aegyptium. It was seen that tortoises were heavily infested and lizards were less infested with $H$. aegyptium. It is known that $H$. aegyptium is the reservoir host for the blood parasite Hemoliva mauritanica which is known to intensively cause diseases in tortoises. Sheep and goat breeding is intensive in the area where the ticks were collected. It was concluded that further molecular studies are required to determine whether $H$. aegyptium is the reservoir of the Theileria ovis which is the factor of Theileriosis disease that causes economic loss, yield loss and deaths in these animals and to determine the prevalence of $H$. mauritanica in the tortoises in the area.

\section{References}

1. Apanaskevich D. A.: Host-parasite relationships of the genus Hyalomma Koch, 1844 (Acari, Ixodidae) and their connection with micro evolutionary process. Parazitologia 2003, 38, 515-523.

2.Araya-Anchetta A., Busch J. D., Scoles G. A., Wagner D. M.: Thirty years of tick population genetics: A comprehensive review. Infect. Genet. Evol. 2015, 29, 164-179.

3. Aydin L.: Distribution and species of ticks on ruminants in the southern Marmara Region. Türkiye Parasitol. Derg. 2000, 24, 194-200.

4. Aysul N., Kar S., Yılmazer N., Alp H. G., Gargll A.: Trakya Yöresi'ndeki kaplumbağalarda (Testudo graeca) Hyalomma aegyptium (Lineaus, 1758) 'un yaygınlığı. Pendik Vet. Mikrobiol. Derg. 2010, 37, 53-56. 
5. Baran I., Atatür M. K.: Türkiye Herpeto faunası (Kurbağa ve Sürüngenler). T. C. Çevre Bakanlığı Yay. Ankara 1998, 214

6. Beshkov Vl., Nanev K.: Amphibians an Reptiles in Bulgaria. Pen soft Publishers, Bulgaria 2012.

7.Bodenheimer F. S.: Türkiye'nin Amfibi ve sürüngenleri bilgisine giriş (İngilizceden çeviren: M. Başoğlu). İstanbul Üniversitesi Fen Fakültesi Monografileri (tabii ilimler), sayı: 2, İstanbul 1946.

8. Boyan P., Vladimir P., Popgeorgiev B. G., Plachiski D.: National Action Plan for Tortoises Conservation in Bulgaria, Vers.1, BSPB, NMNHS-BAS, Sofia 2003.

9. Bulum E.: The Herpeto fauna of Small Nemrut Mountain (Tatvan/Bitlis) Doctoral dissertation, Faculty of Science, University of Yuzuncu Y11, Van 2016.

10. Buskirk J. R.: Of the absence of spur-thighed tortoises, Testudo graeca, form Egypt. Chelonian Conserv. Biol. 1996, 2, 118-120.

11.Dudek K., Skórka P., Sajkowska Z. A., Ekner-Grzyb A., Dudek M., Tryjanowski $P$.: Distribution pattern and number of ticks on lizards. Ticks Tick Borne Dis. 2016, 7, 172-179.

12. Despommier D. D., Gwadz R. W., Hotez P. J., Knirsch C. A.: Parasitic Diseases Apple Trees Prod., New York 2000.

13. Gasc J. P., Cabela A., Crnobrnja-Isailovic J., Dolmen D., Grossenbacher K. Haffner P., Lescure J., Martens H., Martínez Rica J. P., Maurin H., Oliveira M. E., Sofianidou T. S., Veith M., Zuiderwijk A.: Atlas of amphibians and reptiles in Europe. Collection Patrimoines Naturels, 29, Societas Europaea Herpetologica, Muséum National d'Histoire Naturelle \& Service du Petrimone Naturel, Paris 1997, p. 496.

14. Gazyağci S., Aşan N., Demirbas Y.: A common tortoise tick, Hyalomma aegyptium Linne 1758 (Acari: Ixodidae), identified on eastern hedgehog (Erinaceus concolor Martin 1838) in Central Anatolia. Turk. J. Vet. Anim. Sci. 2010, 34, 211-213.

15. Hoogstraal H., Kaiser M. N.: Some host relationships of the tortoise tick, Hyalomma (Hyalommasta) aegyptium (L.) (Ixodoidea, Ixodidae) in Turkey. Ann. Entomol. Soc. Am. 1960, 53, 457-458.

16. Hoogstraal H., Santana F. J., Peenen P. F. D.: Ticks (Ixodoidea) of Mt. Sontra. Danang, Republic of Vietnam. Ann. Entomol. Soc. Am. 1968, 61, 722-729.

17. Jongejan F., Uilenberg G.: The global importance of ticks. Parasitol. 2004, 129, 3-14.

18. Karaer Z., Guven E., Nalbantoglu S., Kar S., Orkun O., Ekdal K., Kocak A., Akcay A.: Ticks on humans in Ankara, Turkey. Exp. Appl. Acarol. 2010, 10.1007/s10493-010-9417-1.

19. Karaoğlu Ö., Özdemir Y., Tolluoğlu A. Ü., Karablylkoğlu M., Köse O., Froger F. Stratigraphy of the Volcanic Products Around Nemrut Caldera: Implications for Reconstruction of the Caldera Formation. Turkish J. Earth Sci. 2005, 14, 123-143.
20. Kerville G. H.: Voyage Zoologique D'Henri Gadeau de Kerville en AsieMineure (Avril-Mai 1912). Tome premiere, premiere Partie, Paris 1939.

21. Kolonin G. V.: World distribution of ixodid ticks. Genera Hyalomma, Aponomma, Amblyomma. IzdNauka, Moscow 1983.

22. Labuda M., Nuttall P. A.: Tick-borne viruses. Parasitol. 2004, 129, 221-245.

23. Özcan A. F., Yıldız M. Z., Akman B., Ĭğci N., Sami E., Sarıkaya B., Göçmen B.: Bitlis İlinin Herpeto faunası Hakkında Ön Calıșma. II. Ulusal Zooloji Kongresi, 28-31 Ağustos 2015, Afyon, p. 8.

24. Paștiu A., Matei I., Mihalca A. D., D 'Amico G., Dumitrache M. O., Kalmár Z., Sándor A. D., Lefkaditis M., Gherman C. M., Cozma V.: Zoonotic pathogens associated with Hyalomma aegyptium in endangered tortoises: evidence for host-switching behaviour in ticks? Parasites Vectors 2012, 5, 1.

25. Razmjo M., Bahrami A., Hosseini E., Bahrami A. M.: The first report of lizard and turtle ticks from Ilam, Western Province of Iran. Adv. Biores. 2013, 3, $118-122$

26. Sindaco R., Venchi A., Carpaneto G. M., Bologna M. A.: The reptiles of Anatolia: a check list and zoo geographical analysis. Biogeographia 2000, $21,441-554$

27. Široký P., Erhart J., Petrželková K. J., Kamler M.: Life cycle of tortoise tick Hyalomma aegyptium under laboratory conditions. Experim. Appl. Acarology $2011,54,277-284$

28. Široký P., Mikuliček P., Jandzik D., Kami H., Mihalca A. D., Rouag R., Kamler M., Schneider C., Záruba M., Modrý D.: Co-distribution pattern of a haemogregarine Hemolivia mauritanica (Apicomplexa: Haemogregarinidae) and its vector Hyalomma aegyptium (Metastigmata: Ixodidae). J. Parasitol. 2009, 95, 728-733.

29. Široký P., Petrželková K. J., Kamler M., Mihalca A. D., Modrý D.: Hyalomma aegyptium as dominant tick in tortoises of the genus Testudo in Balkan countries, with notes on its host preferences. Experim. Appl. Acarology 2006, 40, 279-290.

30. Tiar G., Tiar-Saadı M., Benyacoub S., Rouag R., Široký P.: The dependence of Hyalomma aegyptium on its tortoise host Testudo graeca in Algeria. Med. Vet. Entomol. 2016, 30, 351-359.

31. Vatansever Z., Gargili A., Aysul N. S., Sengoz G., Estrada-Peña A.: Ticks biting humans in the urban area of Istanbul. Parasitol. Res. 2008, 102, 551-553.

32. Yılmaz A. B., Değer S., Bulduk B.: Prevalance of tick infestations on tortoise (Testudo graeca, Linnaeus, 1758). YYU Veteriner Fakultesi Dergisi 2013, 24, 69-74.

Corresponding author: Asst. Prof Ali Bilgin YILMAZ, Van Health High School, University of Yuzuncu Yil, 65080, Van, Turkey; e-mail: alibilginyilmaz@yyu.edu.tr 